\title{
UNDERSTANDING SELLERS’ AGENTS IN THE RESIDENTIAL PROPERTY MARKET
}

\author{
Chuyi XIONG (D), Ka Shing CHEUNG (i) * \\ Department of Property, The University of Auckland, Auckland, New Zealand
}

Received 21 February 2020; accepted 22 July 2020

\begin{abstract}
Buyers in the property market often use an agent who is employed by the seller to assist their home searches. This unique and widely used agency arrangement in the property market is known as "sellers' agents". While principal-agent theory advocates that buyers should directly hire their agents (i.e., buyers' agents) to do the home-hunting, search theory however implies that sellers would employ their agents (i.e., sellers' agents) to increase the probability of the sale and selling prices. Although sellers' agents and buyers' agents are two very distinct institutions, many previous studies assume that their agency characteristics are identical and provide limited insights on how such a seemingly subtle but crucial agency arrangement affects transaction outcomes. Using transaction data from Wuhan China, this study disentangles the effects of the buyers' and sellers' agents on properties' selling prices and their time on the market. The findings indicate that on average transactions conducted by sellers' agents will be associated with a significant selling price premium of around 3.4\%. As a critical test, we further show that the transactions completed by sellers' agents with selling price premiums will have a shorter marketing time than those completed by buyers' agents.
\end{abstract}

Keywords: sellers' agents, search theory, overpricing, time on the market, online listing, second-hand real estate market.

\section{Introduction}

In the property market, many agents who assist the buyer in searching are employed by the seller. In the strategic property management literature, this unique agency relationship is referred to by the term "sellers' agents". On the surface, this contractual arrangement should never be optimal as it lacks incentives to motivate sellers' agents to act in the best interest of buyers (i.e., the principal-agent problem). Nevertheless, such a unique agency relationship does exist as sellers are able to increase the probability of selling the house by reducing buyers' search costs. Bagnoli and Khanna $(1987,1991)$ developed a theoretical model to explain that the existence of sellers' agents is due to the fact that the information about the property can only be communicated to the buyer through the time-consuming home inspection, and the cost of such search activities is non-trivial.

Notwithstanding such a unique agency relationship, the existing research on property agents tends to obscure the difference between seller agents and buyer agents (Yavas, 1994). As a result, many empirical studies of property agents offer only limited insights on how this unique agency characteristic affects sales outcomes. This study aims to fill this research gap by disentangling the role of buyers' agents and sellers' agents in residential property transactions: in particular, their impact on sale prices and time on the market. We first apply the sellers' agent model (Bagnoli \& Khanna, 1989) to develop our testable hypotheses, and we argue that those transactions that use sellers' agents will be associated with a price premium. Also, the resultant time on the market will depend on the price premium/discount entailed. Given that the selling price carries a premium, agents should have the incentive to shorten the price negotiating process, and hence the property will have a shorter the time on market. While the selling price is lower (or at a discount), agents should have the incentive to lengthen the negotiation process.

This study utilises the novel transaction data sourced from one of the largest real estate brokerages in China, the "Lianjia"l Real Estate Agency Co., Ltd. (formerly called

\footnotetext{
1 Lianjia, formerly called Homelink, is a Chinese real-estate brokerage company founded in 2001. As of 2019, it has approximately 6,000 brokerage offices and more than 120,000 brokers. As of 2019, Lianjia has 51 subsidiaries, all related to the real-estate services, such as long-term rental apartment development, real-estate financing or decoration. By 2018, Lianjia's market value reached US\$6 billion.
}

${ }^{\star}$ Corresponding author. E-mail: william.cheung@auckland.ac.nz 
Homelink), between years 2016 and 2019, in the inland metropolis of Wuhan, to empirically test the use of sellers' versus buyers' agents on property market outcomes. The city of Wuhan is used as our case for the following reasons. First, unlike many mature property markets in which a central information gathering system is available (e.g. the Multiple listing service, MLS in the United States; see Allen et al., 2018), homebuyers in China rely substantially on the use of property agents. The reliance on agents (regardless of whether they are buyers' or sellers' agents) in a leading Chinese city offers an intriguing case study to examine the principal-agent relationship thoroughly. Second, most of Wuhan's urban residents live in seven densely populated core districts, while the surrounding suburban districts are mostly rural. This concentrated urban landscape of Wuhan provides us with relatively good control of spatial variability in housing prices. Third, Wuhan is a top-tier city in China, with the residential transaction turnover ranking third among all cities. This indicates that Wuhan has an active housing market that offers us a captivating case to study. More importantly, the Wuhan's Housing Security and Management Bureau is keen to regulate online information dissemination regarding second-hand property transactions. This policy helps ensure high-quality and trustworthy data online (Wuhan Housing Security and Management Bureau, 2018).

Our study is novel for several reasons. First, there is a paucity of literature providing direct evidence to dissect the influence of sellers' agents (versus buyers' agents) on transacted prices and time on the market. To the best of our knowledge, little research has been done to understand the different effects of buyers' and sellers' agents on transaction outcomes. Many previous studies have considered these two institutions of agency as having the same behavioural impacts on housing transactions, while other research mainly focuses on the dual agency problem and ignores such unique agency relationships. The only exceptions are perhaps Bagnoli and Khanna $(1987,1991)$, but these two papers offer only a mathematical explanation of why, and under what conditions, buyers use agents employed by sellers. Even though Elder et al. (2000) did attempt to empirically unveil the effect of buyers' brokers on market outcomes, their study did not compare buyers' brokers with sellers' brokers. Second, this study discusses the effects of agents only in the second-hand property market by using online listing information. Many previous studies related to the agent's effect on home sales in the United States use the data from the Multiple Listing Service (MLS). These studies combine the first-hand and second-hand real estate market (Levitt \& Syverson, 2008; Yavas \& Yang, 1995). Our study discusses only the secondhand market, and therefore minimises the heterogeneity of two markets and avoids the impact resulting from different policies targeting the first-hand market in China. In addition, the transactions in the second-hand real estate market account for about $34 \%^{2}$ of total housing transactions. The online listing information has remarkable advantages in providing accurate, timely and easy-to-search housing-related information for agents, buyers, and sellers to access. Besides the problem of data manipulation can also be mitigated (Wang et al., 2020). Furthermore, relatively few previous studies explore the influence of agents in the China real estate market, mainly because of the lack of regulations for real estate agents in the country (Li \& Wang, 2006; Zhou et al., 1999). With the property market being more formalised and regulated in China, the availability of public property data and the importance of agents' role on the property market begin to gather traction in revisiting the property agents' influence in this fast-changing residential property market. That is also one of the main objectives of this paper.

The rest of the paper is structured as follows. Section 1 will provide a brief literature review on the market for brokerage. Section 2 will develop our testable hypotheses based on the agent model by Bangnoli and Khanna (1987, 1991). Section 3 will describe the data used for the design and the empirical setup for the hypotheses testing. The empirical results will be presented in section 4 . Last section will conclude the paper.

\section{Literature review}

Many studies have discussed the impacts of real estate agents on property transactions, using two main market outcomes, namely the selling prices and the time on the market (Owen, 1977; Yinger, 1981; Anglin \& Arnott, 1991; Benjamin et al., 2000; Jud \& Winkler, 1994; Wiley et al., 2013; Curto et al., 2015; Ferreira \& Jalali, 2015; Yechiam et al., 2017). On the selling price dimension, Jud and Frew (1986) found that in Charlotte, North Carolina, housing prices in the agent-assisted market were higher than in the "by-owner" market. Salant (1991) further suggested that the agents' commission may influence the asking price of the houses. Hughes (1995) and Zumpano et al. (1996) both showed that real estate agents had a positive effect on the selling price, and the former further suggested that houses sold by larger brokerage firms tend to have higher selling prices.

Regarding the time-on-market, much previous literature has focused on the effect of using real estate agents (Yang \& Yavas, 1995; Allen et al., 2015; Yang \& Smeal, 1995; Sirmans et al., 1991). Also, Haurin (1988) indicated that larger brokerage firms had a relatively shorter marketing time than did smaller brokerage firms. The effects of brokerage firm size on time on the market were confirmed by Jud et al. (1996) and Larsen and Park (1989). Goodwin et al. (2014) explored the words used by different brokers to market the property and found that brokers' description of the property could affect the listing's performance characteristics, such as the number of days on the market.

\footnotetext{
2 Source: Ministry of Housing and Urban-Rural Development of China (MOHURD).
} 
Benefield et al. (2011) and Wiley et al. (2011) found that the limited services brokerages provided sped up the sale and increased the selling price. Fereidouni (2012) indicated that the increased number of total real estate agents in Iran and their marketing activities positively significantly stimulated housing prices and rents.

Moreover, some literature has focused on the impact of agents on property transactions, mainly from the perspective of buyer agents (Colwell et al., 1993; Yavas \& Colwell, 1999). Benjamin and Chinloy (2000) analysed the detached dwelling transaction data in the Washington D.C. area and found that buyers' agents tended to increase the listing price to capture extra return. Baryla and Ztanpano (1995) indicated that buyers' agents affected homebuyers in three ways: improving the marginal search efficiency, reducing search costs, and providing more accurate information that assisted buyers to interpret the distribution of house prices better. Other real estate agent literature includes discussions of factors influencing property transactions, such as imperfect information and multiple listing services by brokers (Wu \& Colwell, 1986), and the structural characteristics and pricing strategies of the brokerage (Crockett, 1982; Geltner et al., 1991; Han \& Strange, 2015; Zumpano et al., 1993; Teixeira, 1995).

A substantial body of literature has focused on the determinants of individual agents' capability on real estate selling (Anglin \& Arnott, 1991; Baryla \& Ztanpano, 1995; Haag et al., 2000; Gay \& Zhang, 2014). Glower and Hendershott (1988) found that the educational background of individual agents influenced their sales performance: agents with degree sold houses faster and sold at higher prices. Crellin et al. (1988) and Abelson et al. (1990) provided evidence to support the positive relationship between agents' educational backgrounds and their real estate transactions. Moreover, Abelson et al. (1990) found that married and female agents sold property faster, and were usually higher performers than male agents. Also, many previous studies have discussed the effects of characteristics of individual agents, including race, previous working experiences, the license owned, perceptions of the real estate industry, and hours worked, on prices and time on the market (Follain et al., 1987; Sirmans \& Swicegood, 1997; Jud \& Winkler, 1998).

Turnbull and Dombrow (2007) suggested that agents who specialised in listing properties obtained higher prices for their sellers while those who specialised in selling obtained lower prices for their buyers. The greater scale of listing and selling activity by an agent tends to lower the selling price and to lengthen the time on the market. By comparing the selling of houses owned by agents with those owned by clients, Levitt and Syverson (2008) concluded that if the agents had more information, the homes might sell for a relatively higher price and be longer on the market. Johnson et al. (2004) investigated the relationship between bonuses for agents and their performance in the house selling and found that real estate offering a bonus experienced longer marketing time and lower property prices. More recently, Arndt et al. $(2013,2017)$ found that segments of custom- ers were not necessarily drawn to similar agents or more attractive ones. Wong and Cheung (2017) argue that landlord may exploit tenants who have made non-redeployable investments and charge them an occupancy premium. Verstraete and Verhaeghe (2020) suggested that the real estate agent would ethnically discriminate the rental candidates based on the owners' ethical preference.

However, little research has been done on the differences between buyer agents and seller agents on transaction outcomes. As advocated by Findlay and Gibb (1998) in their study of estate agency pricing in Scotland, more research is needed within the broader analysis of local housing markets on estate agency and conveyancing markets. While Bagnoli and Khanna $(1987,1991)$ developed a theoretical model to explain that the exorbitant cost of personal investigation of houses is the main reason that buyers use agents employed by sellers, they did not put forward their theories to test. In the ensuing section, we will use Bagnoli and Khanna (1987)'s model as a basis for developing our hypotheses concerning both sale price and time on the market and will use the transaction data in a Chinese city to test these hypotheses.

\section{A simple model of buyers' and sellers' agents}

In this section, we present a simple model based on Bagnoli and Khanna $(1987,1991)$ and Johnson et al. (2007) to derive hypotheses which can be tested empirically ${ }^{3}$. Consider houses as a vector of characteristics $\omega$ and the buyers' reservation price for a home as $r(\omega)$. Assume that each seller has a reservation price $c(\omega)$. Each seller chooses a listing price, $p(\omega)$, at which he plans to sell his house. The buyers know only the distribution of vectors $(p, w)$ available but must personally search to inspect the characteristics of a particular home. The seller is assumed to choose a listing price to maximise his expected profits (i.e., capital gains from the sales in this case), which are:

$$
\pi(\omega, p)=\left\{\begin{array}{c}
p-c(\omega) \text { if } r(\omega) \geq p \\
0 \text { otherwise, no sales }
\end{array} .\right.
$$

If the buyers have different reservation prices that are unknown to sellers, Bagnoli and Khanna (1987) suggest that we can let the probability that no buyer's reservation price is larger than some number $x$ be $G(x ; \omega)$, and the seller's expected profit will be $(p-c(\omega))(1-G(p ; \omega))$. The seller chooses the price $p^{*}$ that satisfies:

$$
\pi\left(\omega, p^{*}\right)=p^{*}-c(\omega)=\frac{1-G\left(p^{*} ; \omega\right)}{g\left(p^{*} ; \omega\right)} \equiv \frac{1}{\lambda\left(p^{*}\right)},
$$

where: $\lambda\left(p^{*}\right)$ is the hazard rate of the distribution $G$. It is intuitive that if sellers increase the price by a dollar, the capital gains (profit) $\pi(\omega, p)$ will increase by that dollar with probability $1-G\left(p^{*} ; \omega\right)$, while the denominator measures the likelihood sellers lose the deal.

\footnotetext{
3 While the hypotheses can be derived by many simple models, we would like to follow the intuition of Bagnoli and Khanna $(1987,1991)$ to save the effort to mathematically prove the existence of equilibrium.
} 
To understand the behaviour of sellers' agents, we can examine the probability of selling a house in this theoretical setting (Johnson et al., 2007; Brastow et al., 2012; Waller \& Marks, 2010). The introduction of a seller's agent reduces the buyer's search costs and hence increases the probability of buyers investigating houses. To make this maximisation problem tractable, we can further assume an extreme that every buyer search using the seller's agents. Since every buyer search, the seller can now set his price equal to the maximum reservation price. If this value is $\bar{r}(\omega)$, the seller's expected profit becomes $\bar{r}(\omega)-c(w)-s_{a}$ where $s_{a}$ is the fee is for using the sellers' agents.

Without the use of the sellers' agents, the probability that a house being sold is $1-G\left(p^{*} ; \omega\right)$, but with sellers' agents, the house is sold whenever the maximum reservation price, $\bar{r}(\omega)>c(w)+s_{a}$ is reached. That means the use of the seller's agent increases the probability of selling the house and enables it to be sold at a higher price

$\left.\overline{(r}(\omega)>p^{*}(\omega)\right)$. When sellers do not have agents, the $p^{*}(\omega)$ is strictly less than the largest reservation price $\bar{r}(\omega)$ of any buyer who is searching, because the seller faces a trade-off when choosing the price.

Hypothesis 1 (H1): Ceteris paribus, the use of sellers' agents $\left(A G T_{S}\right)$ will entail higher selling prices.

With the reduction in search costs, sellers can induce more buyers to search. As one increases the selling price $p^{*}$, the profit $\pi\left(\omega, p^{*}\right)$ rises if the seller still sells the house, but that lowers the probability of sale $1-G\left(p^{*} ; \omega\right)$.

$$
\pi(\omega, p)=p-c(\omega)=\frac{1-G\left(p^{*} ; \omega\right)}{g\left(p^{*} ; \omega\right)} .
$$

In this simple model, buyers have no incentive to withhold their reservation prices from the seller's agent, and the agent has a motivation to confine the search intensity. But, in reality, if we allow the buyer and seller to bargain over the selling price $p^{*}(\omega)$. Certainly, we can introduce the mixed-strategy equilibrium (i.e., the Nash equilibrium) analysis for tracing the equilibrium prices, but for the empirical test, we would intuitively argue that the selling price would be subject to the price premium/discount implied from H1. Given that the selling price is higher (or a premium), the agents (either representing sellers or buyers) will have an incentive to shorten the price negotiations process. When the selling price is lower (or a discount), agents will have the incentive to lengthen the negotiation process to secure a favourable price outcome. The resultant time on the market will depend on the price premium/discount entailed.

Hypothesis 2 (H2): Ceteris paribus, transactions conducted by agents with a higher (lower) selling price will attribute a shorter (longer) time-on-the market (TOM).

\section{Research design}

In China's second-hand real estate market, a seller could either post the property information online by themselves or contact one agent to list his/her property for sale, and if the property information posted by the seller, an agent will be assigned to inspect relevant information and to list the house $\mathrm{e}^{4}$. Both online designated agents and agents contacted by the seller are regarded as sellers' agents. A potential buyer could contact the agent for details and request to have the house inspection. Meanwhile, delegate potential buyers can walk in any chain stores of the brokerage and agents will serve these potential buyers. The agents serving potential buyers, either online or offline, are regarded as buyers' agent ${ }^{5}$. In the meantime, sellers would delegate a listing agent to market their properties. The brokerage's website contains a section entitled "Listing Property" with the listing agent's contact information. Agents usually need to compete with their rivals to be the listing agent of a property based on their performance. Therefore, the listing agent who is usually the seller's agent (or could possibly be buyers' agent in some cases) ${ }^{6}$. Once the property was successfully sold, the website will mark the deal as "sold", and the corresponding agent ${ }^{7}$ who contributed the most in the entire transaction process will be indicated. That corresponding agent will receive the major part of the commission from the transaction. The information also reveals whether the agent is a buyers' agent or sellers' agent. We make use of this information to identify whether this is the seller's agent or buyer's agent in this study.

\subsection{Empirical model}

The main objective of this study was to test how sellers' versus buyers' agents affect: (1) the transacted prices; and (2) the time-on-market (TOM) of the property.

To test the H1, whether the housing transaction with seller agents gives a price premium, we specify the following Equation:

$\ln P_{n}=\alpha_{0}+\alpha_{n} \ln \boldsymbol{X}_{n}+\beta_{i} \boldsymbol{A G} \boldsymbol{T}_{\boldsymbol{i}}+\rho_{j} A G T E X P_{j}+\gamma_{m} D_{m}+\varepsilon$,

where: $\ln P$ is the natural logarithm of property prices. $\boldsymbol{X}_{\boldsymbol{n}}$ is a vector of hedonic variables including, size, age, lease

${ }^{4}$ If the seller posted the information online by themselves, it will be shown on the brokerage's internal system, the brokerage will assign an agent from the nearest chain store to contact the seller, and the property will be listed after the agent's inspection.

5 Potential buyers may be interested in diverse properties in different communities and districts. Thus, they can contact any agents to be their corresponding agents. All agents ever served potential buyers are regarded as buyers' agents.

6 The listing agent is the seller's agent and is appointed by the seller to help them search buyers and facilitate the price negotiation process.

7 The agent who brings about the sale is the one who receives the commission. 
term, lift ratio and the overall second-hand housing price indices of Wuhan, China. A set of dummy variables, $D_{m}$ including the bedroom (BEDR), bathroom (BATHR), the direction of the flats (DIR), and the extent of property decoration (DEC) are entered into the equation as the control. Agents' length of work experience (AGTEXP, in categorical years) is also included. $\varepsilon$ is the error term.

Equation (4) was estimated with different types of agents $\boldsymbol{A} G \boldsymbol{T}_{\boldsymbol{i}}$ used in the transaction. When the subscript $i=S$, it represents the use of seller agents in the transaction, while $i=B$ means the buyer agent is used. That means $A G T_{S}$ is the indicator variables where $=1$ if it is a deal done by a seller's agent, $0=$ otherwise; and $A G T_{B}=1$ represents the buyers' agent, $0=$ otherwise. Given that $\mathbf{H 1}$ is confirmed, the coefficient $\beta_{S}$ is expected to be positive $\left(\beta_{S}>0\right)$ with $A G T_{S}$, while the coefficient $\beta_{\mathrm{B}}$ is expected to be less positive (or even negative) when the buyer agents $A G T_{B}$ are used.

Hypothesis 2 (H2) suggests that for the property with a higher selling price (i.e., sellers' agents in this case), a shorter time-on-market will be exhibited (as compared to buyers' agents). The proposed regression model to test the $\mathbf{H} \mathbf{2}$ is as follows:

$$
\begin{aligned}
& \ln \operatorname{TOM}_{k}=\omega_{0}+\omega_{n} \ln \boldsymbol{V}_{\boldsymbol{n}}+\varphi_{s} \ln A D J P_{s}+\mu_{\mathrm{i}} \boldsymbol{A G} \boldsymbol{G}_{\boldsymbol{i}}+ \\
& \rho_{j} A G T E X P_{j}+\delta_{m} M_{m}+\theta,
\end{aligned}
$$

where: $\ln \mathrm{TOM}_{k}$ is the natural logarithm of the property's time on the market. Similarly, to Equation (2), $V_{i}$ is a vector of hedonic variables including, size, age, lease term, lift ratio and the overall second-hand housing price indices of Wuhan, China. $\ln A D J P_{s}$ indicates the natural logarithm of the property overpricing. AGTEXP represents the length of work experience for agents (in categorical years). Compared to Equation (4), the main difference of Equation (5) is that it includes the overpricing ${ }^{8}$ measures (i.e., $\ln (A D J P))$. Yavas and Yang (1995) suggest that the listing price, rather than sales prices, would affect how long the transaction takes and thus the time-on-themarket (TOM) should be the results from the bargaining between the seller and the buyers. Besides, McGreal et al. (2010) suggested that the departure between list price and sale price are varied across the market cycle and related to the time on the market. Therefore, empirically speaking, instead of using sales price $\left(P_{s}\right)$ as the explanatory variables for Equation (5), we incorporate the overprice measure. Given $P_{L}$ be the listing price for each transaction and $P_{s}$ be the selling price; we derive the overpricing measure as $P_{\text {over }}=\left(P_{L}-P_{s}\right) / P_{s}$. As we need to have a logarithmic transformation for $P_{\text {over }}$, we further rescale the variable as non-negative, i.e., $\ln (A D J P)$ where $A D J P=P_{\text {over }}+1-\operatorname{Min}\left(P_{\text {over }}\right) . A G T_{S}$ is an indicator variable where $=1$, if it is a deal done by sellers' agent, $0=$ otherwise. $A G T_{B}=1$ represents the buyers' agent, $0=$ otherwise. A set dummy variable $M_{m}$, including the bed-

\footnotetext{
8 The overpricing measure is the ratio of listing price to selling price, which denotes the magnitude by which the listing price exceeds the selling price.
}

room (BEDR), bathroom (BATHR), the direction of the flats (DIR), and the degree of property decoration (DEC) are covered as controls. $\theta$ is the error term.

$$
\begin{aligned}
& \ln A D J P_{s}=\omega_{0}+\omega_{n} \ln \boldsymbol{V}_{\boldsymbol{n}}+\mu_{\mathrm{i}} \boldsymbol{A} \boldsymbol{G} \boldsymbol{T}_{\boldsymbol{i}}+\rho_{j} A G T E X P_{j}+ \\
& \delta_{m} M_{m}+\theta .
\end{aligned}
$$

To test the $\mathrm{H} 2$ further, controlling for endogeneity, we utilise the two-stage predictor substitution (2SPS) model. In the 2SPS model for time on the market (TOM), we assume that the overpricing measure $(A D J P)$ is endogenous. Therefore, in the first stage, we regress the natural logarithm of the overpricing measure $\left(\ln A D J P_{s}\right)$ on all independent variables by using the least-squares model presented in Equation (6). In the second stage, we use the predicted fitted values from the regression in the first stage as a substitution of the endogenous variable, and apply it in Equation (5). This method is based on the two-stage least square (2SLS) approach applied in the similar study (Norton \& Van Houtven, 2006; Shin \& Moon, 2007; Cain et al., 2019).

As $\mathbf{H} 2$ suggested, given that $A G T_{S}$ in Equation (4) shows a price premium (i.e., $\beta_{s}>0$ ), the sign of $\mu_{s}$ is expected to be less than that of $A G T_{B}$ (i.e., $\mu_{B}>\mu_{s}$ ). Intuitively, agents opt to higher (lower) their expected profits with the trade-off of shortening (lengthening) the time that the property is on the market. The difference in marketing time between sellers' agent and buyers' agents tells us such trade-off.

\subsection{Data}

The data used in this study are sourced from "Lianjia" (Homelink Real Estate Agency Co., Ltd) in Wuhan, China. Lianjia is one of the largest real estate brokerages in China, and its core business targets the second-hand real estate market. The sample period of the data was from January $2016^{9}$ to March 2019 (2016M1 to 2019M3). The data recorded residential property sales from 14 districts in Wuhan, covers 2,322 communities and involving 2,173 individual real estate agents. The transaction data contained the characteristics of each property, including their listing prices, selling price, and more importantly, whether a transaction was typically completed by sellers' agent or buyers' agent. A unique identifier was used to match the transaction data and agent information. Excluding duplicated listings and those with missing data, more than 19,000 housing transactions and more than 2,000 real estate agent's information could be used.

Because the presales markets might behave very differently from the spot sales market (Wong et al., 2007), we exclude presales transactions (with building age less than zero; AGE < 0) from our analysis. (NB Buildings aged less than zero have been pre-sold, having not yet been completed). Some outliners such as the transaction with a very long time-on-the-market are removed from

\footnotetext{
9 Lianjia published historical transaction data pertaining to Wuhan, starting from January 2016.
} 
Table 1. Description of variables and summary statistics

\begin{tabular}{|l|l|c|c|c|c|}
\hline \multicolumn{1}{|c|}{ Variable } & \multicolumn{1}{c|}{ Description } & Mean & S.D. & Min & Max \\
\hline TOM & Time on the market & 61.295 & 70.192 & 1 & 739 \\
\hline $\mathrm{P}_{\mathrm{L}}$ & Listing price (in million RMB) & 1.775 & 1.063 & 5 & 19 \\
\hline $\mathrm{P}_{\mathrm{S}}$ & Selling price (in million RMB) & 1.729 & 1.027 & 4 & 19 \\
\hline $\mathrm{P}_{\text {over }}$ & Overpricing measure & 0.027 & 0.041 & -0.314 & 1.85 \\
\hline HPI & Second-hand housing price index (monthly) & 132.221 & 11.802 & 103.1 & 147.8 \\
\hline AGE & Building age & 8.551 & 5.605 & 1 & 38 \\
\hline SIZE & Size of the house & 93.479 & 36.002 & 12.25 & 395 \\
\hline LEASETERM & Lease term of the house & 69.848 & 1.852 & 40 & 70 \\
\hline LIFTR & Household and lift ratio & 2.878 & 2.195 & 0.364 & 34 \\
\hline AGTEXP & Agents' year of work experience & 3.362 & 1.151 & 1 & 6 \\
\hline BEDR & Numbers of bedrooms & 2.354 & 0.859 & 0 & 9 \\
\hline BATHR & Numbers of bathrooms & 1.281 & 0.507 & 0 & 6 \\
\hline FLR & The floor level of the house & 2.032 & 0.864 & 0 & 1 \\
\hline DEC & Decoration of property & 2.019 & 0.68 & 0 & 1 \\
\hline
\end{tabular}

Notes: BEDR represents $(1=$ property with $i$ bedroom, $0=$ otherwise; $i=0,1,2,3,4,5,6,7,9)$; BATHR represents $(1=$ property with $i$ bedroom, $0=$ otherwise; $i=0,1,2,3,4,5,6) ; D I R_{i}=$ Direction of the property $(1=$ the direction $i, 0=$ otherwise; $i=\mathrm{N}$ (North), NE (Northeast), $\mathrm{E}$ (East), SE (Southeast), S (South), SW (Southwest), W (West), NW (Northwest)); FLR $R_{i}=$ the floor of the property $(1=$ the floor is categorized $i, 0=$ otherwise; $i=\mathrm{HIGH}$ (High floor), MID (Middle floor), LOW (Low floor)); $D E C_{i}=$ the degree of property decoration $(1=$ the degree of property decoration is $i$, $0=$ others; $i=$ ROUGHCAST (no decoration), SIMPLE (the basic decoration), OTHERS (the general decoration), LUXURY (the luxury decoration); $\operatorname{AGTEXP}_{i}=$ the working years of agent $(1=$ the working years is $(i-1)$ to $i$ year, $0=$ others; $\left.i=1,2,3,4,5,6)\right)$.

the estimation. All in all, the resultant dataset consists of 15,922 sales. Table 1 summarises the descriptive statistics of the variable used in the empirical model.

From the descriptive statistics, we know that the selling prices were 1.729 million on average, and that the transactions were in general overpriced by $2.7 \%$. (i.e., $P_{o v-}$ ${ }_{e r}=0.027$ listing price exceed the selling price by around $2.7 \%)$. The average time on the market (TOM) was approximately two months (or 61 days), but in some cases, the transaction time was up to 24 months (i.e., 739 days). The building age (AGE) is one of the primary considerations of property transactions. The mean of 8.551 suggests that the average building age of the second-hand property market in Wuhan is around eight and a half years. The mean of the lease term ${ }^{10}$ of the house is nearly 70 denotes that most of the properties are 70 years lease term. The households-to-lift ratio (LIFTR), is an important quality indicator that households might consider when they make purchase decisions concerning high-rise residential apartments in China. LIFTR describes the lift ratio, and the mean of 2.878 indicates that one lift services approximately three households per floor. The sellers' agents $\left(A G T_{\mathrm{S}}\right)$ equals 1 when the agent represented the seller for more than $90 \%$ of properties the agent handled. On the other hand, the buyers' agents $\left(A G T_{\mathrm{B}}\right)$ equals 1 when less than $10 \%$ of transactions handled by the agent are a sellside deal. The variable AGTEXP denotes the experience of agents, which is measured by the number of working years of agents accumulated in the property industry. The mean of agents' work experience (AGTEXP) is 3.362. This sug-

\footnotetext{
${ }^{10}$ The lease term refers to the terms of land use rights, usually there are three types of terms for residential properties in China: 40 years, 50 years, and 70 years.
}

gests the average working years of agents are between two to three years in the Wuhan property market. The mean bedrooms (BEDR) of 2.349 indicates that the homes had about two bedrooms on average. The indicator variable (BATHR) suggests that homes in many cases had more than one bathroom. The mean of the dummy variable, facing the South direction, is 0.804 , while the mean value for facing other directions is less than 0.1 indicating that most homes faced South, validating the norm that Chinese people prefer their homes to face South (Wang et al., 2020; Sun 2005). The mean dummy, other decoration, is 0.739 , suggesting that most of the second-hand houses are decorated.

\section{Empirical results and discussion}

Results are presented in Table 2. Column (2) and (3) show the results for Equation (4) with $A G T_{S}$ and $A G T_{B}$ being estimated, respectively. The results of the coefficient for sellers' agents $\left(\beta_{S}\right)$ is significantly positive, whereas the estimated coefficient for buyers' agents $\left(\beta_{\mathrm{B}}\right)$ is significantly negative. The results imply that the use of sellers' agents will be associated with a higher property price. The coefficient indicates when sellers' agents are employed, the price of the property is expected to sell $3.4 \%$ higher than would be the case without a specific agency arrangement (or even with no agents involved). In dollar terms, when sellers' agents exist this price premium averages about RMB 59,000. Meanwhile, the use of buyers' agents causes a discount on selling prices, as evidenced by the negative coefficient of $A G T_{B}$. The coefficient of $A G T_{B}$ suggests a $10.9 \%$ discount for the selling price when buyers' agents are employed. In dollar terms, such a price discount averages about RMB 188,000. These results confirm our H1. 
Table 2. The agents' effect on property prices - buyers' versus sellers' agents

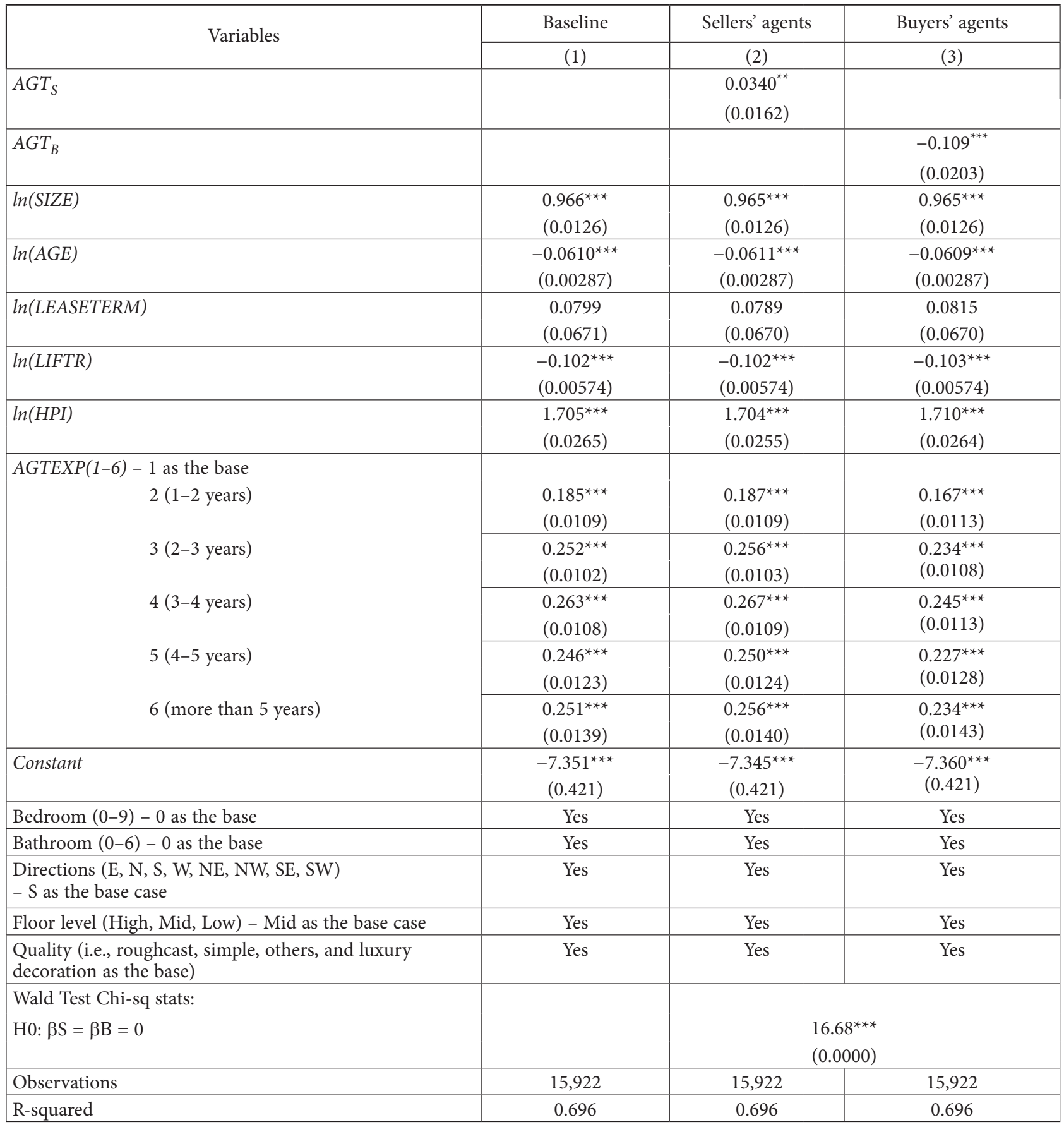

Notes: The dependent variable is the $\ln (S A L E P)$, the natural logarithm of selling prices of property. ${ }^{* * *}$, and ${ }^{* * *}$ are at $10 \%, 5 \%$, and $1 \%$ significance level. Standard errors are in parentheses.

The Wald test (with Chi-square statistics $=16.68$ ) suggests that the coefficients of sellers' agents $A G T_{S}\left(\beta_{\mathrm{S}}\right)$ and buyers' agents $A G T_{B}\left(\beta_{\mathrm{B}}\right)$ are statistically significantly different from each other.

The results for other property characteristics variables are consistent with our expectations. The estimated coefficients for SIZE, AGE, LIFTR and HPI are significantly positive at the $95 \%$ level of confidence. These results imply that the larger the size, the younger the building, the fewer households per lift and the better the market condition would lead to increases in the magnitude of property price, irrespective of whether the agent is a seller's agent or buyer's agent. Notably, the work experience accumulated by agents in the first three to four years within the property industry can help the agent achieve a higher selling price, while such positive impact reaches a plateau after five years. This can be indicated by the significant positive coefficients of the variable AGTEXP. In addition, to further control for differences in the property's characteristics, the dummy variables of the bedroom, bathroom, floor level, as well as the direction and decoration of properties were included in the model. 
Table 3. Time on the market (TOM) of properties - buyers' versus sellers' agents

\begin{tabular}{|c|c|c|c|c|c|}
\hline \multirow{3}{*}{ Variables } & \multicolumn{3}{|c|}{ OLS } & \multicolumn{2}{|c|}{ 2SPS } \\
\hline & Baseline & Sellers' agents & Buyers' agents & Sellers' agents & Buyers' agents \\
\hline & (1) & (2) & (3) & (4) & (5) \\
\hline$A G T_{S}$ & & $\begin{array}{c}0.152^{\star} \\
(0.0637)\end{array}$ & & $\begin{array}{l}0.136^{\star *} \\
(0.0632)\end{array}$ & \\
\hline$A G T_{B}$ & & & $\begin{array}{l}0.263^{\star * *} \\
(0.0985)\end{array}$ & & $\begin{array}{l}0.255^{\star * *} \\
(0.0978)\end{array}$ \\
\hline $\ln (A D J P)$ & $\begin{array}{c}2.617^{\star * *} \\
(0.399)\end{array}$ & $\begin{array}{c}2.596^{\star * *} \\
(0.399)\end{array}$ & $\begin{array}{c}2.611^{\star * *} \\
(0.399)\end{array}$ & $\begin{array}{l}-0.0019 \\
(0.0382)\end{array}$ & $\begin{array}{l}-0.0042 \\
(0.0382)\end{array}$ \\
\hline $\ln (S I Z E)$ & $\begin{array}{l}0.660^{\star * *} \\
(0.0608)\end{array}$ & $\begin{array}{l}0.658^{\star * *} \\
(0.0608)\end{array}$ & $\begin{array}{l}0.661^{\star * *} \\
(0.0608)\end{array}$ & $\begin{array}{c}8.165^{\star * *} \\
(0.438)\end{array}$ & $\begin{array}{c}8.181^{\star * *} \\
(0.438)\end{array}$ \\
\hline $\ln (A G E)$ & $\begin{array}{l}0.0241^{\star} \\
(0.0139)\end{array}$ & $\begin{array}{l}0.0235^{\star} \\
(0.0139)\end{array}$ & $\begin{array}{l}0.0240^{*} \\
(0.0139)\end{array}$ & $\begin{array}{l}-0.444^{*} \\
(0.0307)\end{array}$ & $\begin{array}{l}-0.445^{\star} \\
(0.0307)\end{array}$ \\
\hline $\ln ($ LEASETERM $)$ & $\begin{array}{l}-0.290 \\
(0.324)\end{array}$ & $\begin{array}{c}-0.295^{\star \star} \\
(0.324)\end{array}$ & $\begin{array}{l}-0.294 \\
(0.324)\end{array}$ & $\begin{array}{c}0.319 \\
(0.324)\end{array}$ & $\begin{array}{c}0.321 \\
(0.324) \\
\end{array}$ \\
\hline $\ln ($ LIFTR $)$ & $\begin{array}{c}0.0480^{\star} \\
(0.0278) \\
\end{array}$ & $\begin{array}{c}0.0488^{\star} \\
(0.0278)\end{array}$ & $\begin{array}{l}0.0493^{\star} \\
(0.0278)\end{array}$ & $\begin{array}{c}-0.747^{\star * *} \\
(0.0536)\end{array}$ & $\begin{array}{c}-0.748^{\star * *} \\
(0.0536)\end{array}$ \\
\hline $\ln (H P I)$ & $\begin{array}{c}2.648^{\star * *} \\
(0.128)\end{array}$ & $\begin{array}{c}2.645^{\star * *} \\
(0.128)\end{array}$ & $\begin{array}{c}2.637^{\star * *} \\
(0.128)\end{array}$ & $\begin{array}{c}15.95^{\star * *} \\
(0.777)\end{array}$ & $\begin{array}{c}15.96^{\star * *} \\
(0.776)\end{array}$ \\
\hline $\begin{array}{r}\operatorname{AGTEXP}(1-6)-1 \text { as the base } \\
2(1-2 \text { years })\end{array}$ & $\begin{array}{l}-0.0823 \\
(0.0527) \\
\end{array}$ & $\begin{array}{l}-0.0725 \\
(0.0528)\end{array}$ & $\begin{array}{l}-0.0408 \\
(0.0549)\end{array}$ & $\begin{array}{l}1.347^{\star * *} \\
(0.0980)\end{array}$ & $\begin{array}{l}1.381^{\star * *} \\
(0.0991)\end{array}$ \\
\hline 3 ( $2-3$ years $)$ & $\begin{array}{l}-0.119^{\star *} \\
(0.0494)\end{array}$ & $\begin{array}{l}-0.103^{* *} \\
(0.0498)\end{array}$ & $\begin{array}{l}-0.0740 \\
(0.0521)\end{array}$ & $\begin{array}{l}1.839^{\star * *} \\
(0.123)\end{array}$ & $\begin{array}{l}1.872^{\star * *} \\
(0.124)\end{array}$ \\
\hline 4 (3-4 years) & $\begin{array}{l}-0.0994^{*} \\
(0.0524)\end{array}$ & $\begin{array}{l}-0.0817 \\
(0.0529)\end{array}$ & $\begin{array}{l}-0.0552 \\
(0.0549)\end{array}$ & $\begin{array}{l}1.950^{\star * *} \\
(0.129)\end{array}$ & $\begin{array}{l}1.981^{\star * *} \\
(0.130)\end{array}$ \\
\hline 5 (4-5 years) & $\begin{array}{l}-0.0280 \\
(0.0595)\end{array}$ & $\begin{array}{l}-0.0101 \\
(0.0600)\end{array}$ & $\begin{array}{c}0.0162 \\
(0.0617)\end{array}$ & $\begin{array}{l}1.885^{\star * *} \\
(0.125)\end{array}$ & $\begin{array}{l}1.915^{\star * *} \\
(0.126)\end{array}$ \\
\hline 6 (more than 5 years) & $\begin{array}{l}-0.0366 \\
(0.0672)\end{array}$ & $\begin{array}{l}-0.0173 \\
(0.0676)\end{array}$ & $\begin{array}{l}0.00605 \\
(0.0690)\end{array}$ & $\begin{array}{l}1.929^{\star * *} \\
(0.131)\end{array}$ & $\begin{array}{l}1.957^{\star * *} \\
(0.132)\end{array}$ \\
\hline Constant & $\begin{array}{c}-11.09^{* * *} \\
(2.038)\end{array}$ & $\begin{array}{c}-11.06^{* * *} \\
(2.038)\end{array}$ & $\begin{array}{c}-11.07^{\star * *} \\
(2.038)\end{array}$ & $\begin{array}{c}-67.59^{* * *} \\
(3.872)\end{array}$ & $\begin{array}{c}-67.70^{\star * \star} \\
(3.871)\end{array}$ \\
\hline Bedroom (0-9) -0 as the base & Yes & Yes & Yes & Yes & Yes \\
\hline Bathroom $(0-6)-0$ as the base & Yes & Yes & Yes & Yes & Yes \\
\hline $\begin{array}{l}\text { Directions (E, N, S, W, NE, NW, SE, } \\
\text { SW) - S as the base case }\end{array}$ & Yes & Yes & Yes & Yes & Yes \\
\hline $\begin{array}{l}\text { Floor level (High, Mid, Low) - Mid as } \\
\text { the base case }\end{array}$ & Yes & Yes & Yes & Yes & Yes \\
\hline $\begin{array}{l}\text { Quality (i.e., roughcast, simple, others, } \\
\text { and luxury decoration as the base) }\end{array}$ & Yes & Yes & Yes & Yes & Yes \\
\hline Observations & 15,922 & 15,922 & 15,922 & 15,922 & 15,922 \\
\hline R-squared & 0.072 & 0.072 & 0.072 & 0.087 & 0.087 \\
\hline
\end{tabular}

Notes: The dependent variable is the $\ln (\mathrm{TOM})$, the natural logarithm of marketing time. ${ }^{* * *},{ }^{*}$, and ${ }^{* * *}$ are at $10 \%, 5 \%$, and $1 \%$ significance level. Standard errors are in parentheses.

Table 3 presents the test results for H2. Column (2) and (3) demonstrate the ordinary least regression results for Equation (5) with $A G T_{S}$ and $A G T_{B}$ being estimated. The magnitude of property overpricing has a significantly positive effect on the time on the market (TOM). The incremental impact of the adjusted overpricing on the TOM is 2.617. It means that if the seller "overprices" the listing (or asking) prices of the property relative to the transacted price by one per cent, such overpricing would lead to a
$2.617 \%$ longer marketing time for the property. Besides, the coefficient for sellers' agents $\left(\mu_{S}\right)$ is 0.152 , which is significantly different from zero at the $95 \%$ level of confidence. This implies that the marketing time of properties sold by sellers' agents is on average nine days longer than the properties without specific agency arrangement (or without agents involved). Meanwhile, the coefficient for the buyers' agent $\left(\mu_{B}\right)$ is significantly positive at 0.263 . This indicates that when buyers' agents are employed, it 
will lengthen the time on the market of properties for sixteen days. Column (4) and (5) shows the 2SPS results for marketing time. The coefficients for both sellers' agents $\left(\mu_{S}\right)$ and buyers' agents $\left(\mu_{B}\right)$ are consistent with the OLS results. The coefficient is 0.136 for sellers' agents suggests that the marketing time of properties is eight days longer than the properties without specific agency while the 0.255 for the sellers' agents suggests the fifteen days longer of marketing time if the buyers' agents are employed. As our H2 suggests, sellers' agents (who exhibit a higher price) will have a shorter TOM as compared to buyers' agents (who exhibit a lower price; or even a discount in our case). The results confirm our H2. Both coefficients from 2SPS results are slightly smaller than the OLS results indicates that the endogeneity of having a longer time on the market with an overpriced of property is mitigated by the 2SPS method. Interestingly, most of the results for agents' work experience turn to be significantly positive in 2SPS estimation. This means that agents' experience could not help shorten the marketing time and even lengthen the time on the market. This is reasonable as we hypothesised that the TOM is driven mostly by the price premium/discount. Some control variables for properties' characteristics are consistent with our expectation. (SIZE, HPI). It denotes that the larger size and better market condition could result in a longer time on the market.

\section{Conclusions}

Sellers' agents and buyers' agents represent two distinct contractual arrangements, but previous property research on agency has tended to obscure such unique agency features. This study disentangles the effects of buyers' agents and sellers' agents on properties' selling prices and their time on the market. As is evident in our study, those transactions using sellers' agents are associated with a significant price premium, while such effects do not prevail amongst transactions using buyers' agents. Furthermore, the time on the market is subject to selling prices with different agency arrangements. Transactions conducted by agents with a higher (lower) selling price is shown to be attributable to a shorter (longer) time-on-the market (TOM). In our empirical test, a transaction conducted by a seller's agents (with a selling price premium) is shown to have a shorter TOM as compared to a transaction involving a buyer's agent (with a selling price discount).

The contribution of this study is fourfold. First, this study provides the first empirical evidence to distinguish the distinct effects of sellers' agents and buyers' agents on the two primary transaction outcomes, namely sale price and time on the market. The findings of this study confirm Bagnoli and Khanna's $(1987,1991)$ theoretical explanation of the existence of sellers' agents on the property market, i.e., that sellers' agent benefit sellers by significantly reducing homebuyers' search costs, which is captured by the selling price premium. Second, this case study in a Chinese city challenges the (oversimplified) assumption of previous studies that sellers' agents and buyers' agents are two identical agency arrangements. Indeed, our results are not intended to jeopardise the past research on agency; instead, we would like future research on property agency to be aware of the differences between sellers' and buyers' agents and to develop further material studies in this sphere. Third, this study also suggests that experienced sellers' agents, especially those with three to four years of work experience are more successful in negotiating a higher selling price, while work experience does not help them shorten the marketing time of the properties. Last, this study introduces online listing information from online to offline $(\mathrm{O} 2 \mathrm{O})$ platform as an innovative data source for analysing the agent's effect on property price and time on the market. This novel data source can greatly benefit future studies in China real estate market.

\section{Acknowledgements}

We are also immensely grateful to anonymous reviewers for their comments on an earlier version of the manuscript. Any errors are our own and should not tarnish the reputations of these esteemed persons.

\section{Funding}

This work was financially supported by the University of Auckland Faculty Research Development Fund [FRDF Grant number 3717474].

\section{Author contributions}

Xiong and Cheung conceived of the presented idea. Xiong and Cheung both contributed to the design and implementation of the research, to the analysis of the results and the writing of the manuscript. Both authors reviewed the final manuscript.

\section{Disclosure statement}

There is no competing financial, professional, or personal interests from other parties.

\section{References}

Abelson, M., Kacmar, M., \& Jackofsky, E. (1990). Factors influencing real estate brokerage sales staff performance. Journal of Real Estate Research, 5(2), 265-275.

Allen, M. T., Cadena, A., Rutherford, J., \& Rutherford, R. C. (2015). Effects of real estate brokers' marketing strategies: public open houses, broker open houses, MLS virtual tours, and MLS photographs. Journal of Real Estate Research, 37(3), 343-369.

Allen, M. T., Dare, W. H., \& Li, L. (2018). MLS information sharing intensity and housing market outcomes. The Journal of Real Estate Finance and Economics, 57(2), 297-313. https://doi.org/10.1007/s11146-017-9612-5

Anglin, P. M., \& Arnott, R. (1991). Residential real estate brokerage as a principal-agent problem. The Journal of Real Estate Finance and Economics, 4(2), 99-125.

https://doi.org/10.1007/BF00173119 
Arndt, A., Harrison, D. M., Lane, M. A., Seiler, M. J., \& Seiler, V. L. (2013). Can agents influence property perceptions through their appearance and use of pathos? Housing Studies, 28(8), 1105-1116.

https://doi.org/10.1080/02673037.2013.802292

Arndt, A., Harrison, D. M., Lane, M. A., Seiler, M. J., \& Seiler, V. L. (2017). Real estate agent target marketing: are buyers drawn towards particular real estate agents? Journal of Housing Research, 26(1), 39-52. https://doi.org/10.1080/10835547.2017.12092127

Bagnoli, M., \& Khanna, N. (1987). Why are buyers represented by sellers agents when buying a house? (Working paper). University of Michigan.

Bagnoli, M., \& Khanna, N. (1991). Buyers' and sellers' agents in the housing market. The Journal of Real Estate Finance and Economics, 4(2), 147-156.

https://doi.org/10.1007/BF00173121

Baryla, E., \& Ztanpano, L. (1995). Buyer search duration in the residential real estate market: the role of the real estate agent. Journal of Real Estate Research, 10(1), 1-13.

Benefield, J., Pyles, M., \& Gleason, A. (2011). Sale price, marketing time, and limited service listings: the influence of home value and market conditions. Journal of Real Estate Research, 33(4), 531-563.

Benjamin, J., \& Chinloy, P. (2000). Pricing, exposure and residential listing strategies. Journal of Real Estate Research, 20(1-2), 61-74. https://doi.org/10.1080/10835547.2000.12091026

Benjamin, J., Jud, G., \& Sirmans, G. (2000). What do we know about real estate brokerage? Journal of Real Estate Research, 20(1-2), 5-30. https://doi.org/10.1080/10835547.2000.12091034

Brastow, R., Johnson, K., \& Waller, B. (2012). On the likelihood of a transaction and the amount of time provided the broker to sell property. Journal of Housing Research, 21(2), 215-225. https://doi.org/10.1080/10835547.2012.12092057

Cain, C., Huerta-Sanchez, D., \& Maynard, N. (2019). Housing crisis spillover effects in areas of high concentration of non-primary residences. Journal of Housing Research, 27(2), 159-182. https://doi.org/10.1080/10835547.2018.12092147

Colwell, P. F., Trefzger, J. W., \& Treleven, R. A. (1993). Compensating buyer brokers. Illinois Real Estate Letter, 12-6.

Crellin, G., Frew, J., \& Jud, D. (1988). The earnings of realtors: some empirical evidence. Journal of Real Estate Research, 3(2), 39-78.

Crockett, J. H. (1982). Competition and efficiency in transacting: the case of residential real estate brokerage. Real Estate Economics, 10(2), 209-227. https://doi.org/10.1111/1540-6229.00264

Curto, R., Fregonara, E., \& Semeraro, P. (2015). Listing behaviour in the Italian real estate market. International Journal of Housing Markets and Analysis, 8(1), 97-117. https://doi.org/10.1108/IJHMA-01-2014-0003

Elder, H. W., Zumpano, L. V., \& Baryla, E. A. (2000). Buyer brokers: do they make a difference? Their influence on selling price and search duration. Real Estate Economics, 28(2), 337-362. https://doi.org/10.1111/1540-6229.00804

Fereidouni, H. G. (2012). The role of real estate agents on housing prices and rents: the Iranian experience. International Journal of Housing Markets and Analysis, 5(2), 134-144. https://doi.org/10.1108/17538271211225896

Ferreira, F. A., \& Jalali, M. S. (2015). Identifying key determinants of housing sales and time-on-the-market (TOM) using fuzzy cognitive mapping. International Journal of Strategic Property Management, 19(3), 235-244.

https://doi.org/10.3846/1648715X.2015.1052587
Findlay, J., \& Gibb, K. (1998). The pricing of estate agency and conveyancing services in Scotland. Journal of Property Research, 15(2), 135-151.

https://doi.org/10.1080/095999198368446

Follain, J., Lutes, T., \& Meier, D. (1987). Why do some real estate salespeople earn more than others? Journal of Real Estate Research, 2(1), 73-81.

Gay, S., \& Zhang, A. T. (2014). Expertise value added in the real estate market (Working paper). University of Chicago. https://doi.org/10.2139/ssrn.2515157

Geltner, D., Kluger, B. D., \& Miller, N. G. (1991). Optimal price and selling effort from the perspectives of the broker and seller. Real Estate Economics, 19(1), 1-24. https://doi.org/10.1111/1540-6229.00537

Glower, M., \& Hendershott, P. (1988). The determinants of realtor income. Journal of Real Estate Research, 3(2), 53-68.

Goodwin, K., Waller, B., \& Weeks, H. S. (2014). The impact of broker vernacular in residential real estate. Journal of Housing Research, 23(2), 143-161.

https://doi.org/10.1080/10835547.2014.12092089

Haag, J., Rutherford, R., \& Thomson, T. (2000). Real estate agent remarks: help or hype? Journal of Real Estate Research, 20(1-2), 205-215.

Han, L., \& Strange, W. C. (2015). The microstructure of housing markets: search, bargaining, and brokerage. In Handbook of regional and urban economics (Vol. 5, pp. 813-886). Elsevier. https://doi.org/10.1016/B978-0-444-59531-7.00013-2

Haurin, D. (1988). The duration of marketing time of residential housing. Real Estate Economics, 16(4), 396-410. https://doi.org/10.1111/1540-6229.00463

Hughes, W. (1995). Brokerage firms' characteristics and the sale of residential property. Journal of Real Estate Research, 10(1), $45-56$.

Johnson, K., Anderson, R., \& Benefield, J. (2004). Salesperson bonuses and their impact on residential property price and time on market. Journal of Real Estate Practice and Education, 7(1), 1-14. https://doi.org/10.1080/10835547.2004.12091605

Johnson, K., Benefield, J., \& Wiley, J. (2007). The probability of sale for residential real estate. Journal of Housing Research, 16(2), 131-142. https://doi.org/10.1080/10835547.2007.12091978

Jud, G. D., \& Frew, J. (1986). Real estate brokers, housing prices, and the demand for housing. Urban Studies, 23(1), 21-31. https://doi.org/10.1080/00420988620080031

Jud, G. D., \& Winkler, D. T. (1994). What do real estate brokers do: an examination of excess returns in the housing market. Journal of Housing Economics, 3(4), 283-295. https://doi.org/10.1006/jhec.1994.1014

Jud, G. D., \& Winkler, D. T. (1998). The earnings of real estate salespersons and others in the financial services industry. The Journal of Real Estate Finance and Economics, 17(3), 279-291. https://doi.org/10.1023/A:1007733125056

Larsen, J. E., \& Park, W. J. (1989). Non-uniform percentage brokerage commissions and real estate market performance. Real Estate Economics, 17(4), 422-438. https://doi.org/10.1111/1540-6229.00501

Levitt, S. D., \& Syverson, C. (2008). Market distortions when agents are better informed: the value of information in real estate transactions. The Review of Economics and Statistics, 90(4), 599-611. https://doi.org/10.1162/rest.90.4.599

Li, L. H., \& Wang, C. (2006). Real estate agency in China in the information age. Property Management, 24(1), 47-61. https://doi.org/10.1108/02637470610643119 
McGreal, S., Brown, L., \& Adair, A. (2010). List price and sale price variation across the housing market cycle. International Journal of Housing Markets and Analysis, 3(2), 89-99. https://doi.org/10.1108/17538271011049731

Norton, E. C., \& Van Houtven, C. H. (2006). Inter-vivos transfers and exchange. Southern Economic Journal, 73(1), 157-172. https://doi.org/10.2307/20111880

Owen, B. M. (1977). Kickbacks, specialisation, price fixing, and efficiency in residential real estate markets. Stanford Law Review, 29(5), 931-967. https://doi.org/10.2307/1228140

Salant, S. W. (1991). For sale by owner: when to use a broker and how to price the house. The Journal of Real Estate Finance and Economics, 4(2), 157-173. https://doi.org/10.1007/BF00173122

Shin, J., \& Moon, S. (2007). Do HMO plans reduce health care expenditure in the private sector? Economic Inquiry, 45(1), 82-99. https://doi.org/10.1093/ei-cbl008

Sirmans, C. F., Turnbull, G. K., \& Benjamin, J. D. (1991). The markets for housing and real estate broker services. Journal of Housing Economics, 1(3), 207-217. https://doi.org/10.1016/S1051-1377(05)80033-6

Sirmans, G., \& Swicegood, P. (1997). Determinants of real estate licensee income. Journal of Real Estate Research, 14(2), 137-153.

Teixeira, C. (1995). Ethnicity, housing search, and the role of the real estate agent: a study of Portuguese and Non-Portuguese real estate agents in Toronto. The Professional Geographer, 47(2), 176-183. https://doi.org/10.1111/j.0033-0124.1995.00176.x

Turnbull, G. K., \& Dombrow, J. (2007). Individual agents, firms, and the real estate brokerage process. The Journal of Real Estate Finance and Economics, 35(1), 57-76. https://doi.org/10.1007/s11146-007-9025-y

Verstraete, J., \& Verhaeghe, P. P. (2020). Ethnic discrimination upon request? Real estate agents' strategies for discriminatory questions of clients. Journal of Housing and the Built Environment, 35, 703-721. https://doi.org/10.1007/s10901-019-09721-8

Waller, B., \& Marks, M. (2010). Liquidating real estate assets quickly: what affects the probability of a quick sale? Journal of Real Estate Practice and Education, 13(1), 55-70. https://doi.org/10.1080/10835547.2010.12091669

Wang, X., Li, K., \& Wu, J. (2020). House price index based on online listing information: the case of China. Journal of Housing Economics, 50, 101715.

https://doi.org/10.1016/j.jhe.2020.101715

Wiley, J. A., Waller, B., \& Brastow, R. (2013). Two sides of dual agency: evidence from homebuyers and transactions. Journal of Property Research, 30(1), 47-66. https://doi.org/10.1080/09599916.2012.717538
Wiley, J. A., Zumpano, L. V., \& Benefield, J. D. (2011). The limited-service brokerage decision: theory and evidence. The Journal of Real Estate Finance and Economics, 43(3), 336-358. https://doi.org/10.1007/s11146-009-9217-8

Wu, C., \& Colwell, P. F. (1986). Equilibrium of housing and real estate brokerage markets under uncertainty. Real Estate Economics, 14(1), 1-23. https://doi.org/10.1111/1540-6229.00366

Wuhan Housing Security and Management Bureau. (2018). Announcement of implementing "Agreement for sale and purchase of second-hand residential house (individual)", "Agreement for sale and purchase of second-hand residential house (brokerage)" in Wuhan (Issue No. 50). http://fgj.wuhan.gov.cn/ bsfw_44/bgxz/kfscl_14270/202001/t20200109_712190.shtml

Wong, S. K., Chau, K. W., \& Yiu, C. Y. (2007). Volatility transmission in the real estate spot and forward markets. The Journal of Real Estate Finance and Economics, 35(3), 281-293. https://doi.org/10.1007/s11146-007-9037-7

Wong, S. K., \& Cheung, K. S. (2017). Renewing a lease at a discount or premium? Journal of Real Estate Research, 39(2), 215-234.

Yang, S., \& Smeal, A. (1995). Bigger is not better: brokerage and time on the market. Journal of Real Estate Research, 10(1), 23-33.

Yavas, A. (1994). Economics of brokerage: an overview. Journal of Real Estate Literature, 2(2), 169-195. https://doi.org/10.1111/1540-6229.00668

Yavas, A., \& Yang, S. (1995). The strategic role of listing price in marketing real estate: theory and evidence. Real Estate Economics, 23(3), 347-368.

Yavas, A., \& Colwell, P. (1999). Buyer brokerage: incentive and efficiency implications. The Journal of Real Estate Finance and Economics, 18(3), 259-277. https://doi.org/10.1023/A:1007733916238

Yechiam, E., Ashby, N. J., \& Pachur, T. (2017). Who's biased? A meta-analysis of buyer-seller differences in the pricing of lotteries. Psychological Bulletin, 143(5), 543-563. https://doi.org/10.1037/bul0000095

Yinger, J. (1981). A search model of real estate broker behavior. The American Economic Review, 71(4), 591-605.

Zhou, Y., Liu, P. Y., \& Gao, R. (1999). Fang Di Chan Jing Ji Ren Gai Lun [A conspectus for realty broker]. South-Eastern University Press.

Zumpano, L. V., Elder, H. W., \& Baryla, E. A. (1996). Buying a house and the decision to use a real estate broker. The Journal of Real Estate Finance and Economics, 13(2), 169-181. https://doi.org/10.1007/BF00154054

Zumpano, L. V., Elder, H. W., \& Crellin, G. E. (1993). The market for residential real estate brokerage services: costs of production and economies of scale. The Journal of Real Estate Finance and Economics, 6(3), 237-250. https://doi.org/10.1007/BF01096960 